\title{
健康づくりのための運動基準2006における身体活動量の基準値
} 週23メッッ・時と 1 日あたりの歩数との関連

\author{
村上 晴香 ${ }^{1}$, 川上 諒子 ${ }^{1}$, 大森 由実 ${ }^{2}$, 宮武 伸行 $^{3}$ ，森田 明美 $^{1}$, 宮地 元彦 $^{1}$
}

\section{Translating from 23METs-h/wk as physical activity reference value for Japanese to daily step counts}

\author{
Haruka Murakami ${ }^{1}$, Ryoko Kawakami ${ }^{1}$, Yumi Ohmori ${ }^{2}$, Nobuyuki Miyatake, \\ Akemi Morita ${ }^{1}$ and Motohiko Miyachi ${ }^{1}$ \\ 1 独立行政法人 国立健康 - 栄養研究所， ₹ 162-8636 東京都新宿区戸山1-23-1 (National Institute of Health and Nutrition, \\ 1-23-1 Toyama, Shinjuku-ku, Tokyo 162-8636, Japan) \\ 2 神奈川工科大学, 下243-0292 神奈川県厚木市下荻野1030 (Kanagawa institute of technology, 1030 Shimo-ogino, Atsugi \\ Kanagawa 243-0292, Japan) \\ 3 香川大学, ₹761-0793 香川県木田郡三木町池戸1750-1 (Kagawa University, 1750-1 Ikenobe, Miki-cho, Kita-gun, Kagawa \\ 761-0793, Japan)
}

Received: July 14, 2011 / Accepted: January 10, 2012

\begin{abstract}
A physical activity reference value for health promotion, 23 METs-h/week was established by the Ministry of Health, Welfare, and Labour in Japan in 2006. The purpose of this study was to determine the daily step counts (steps/day) that classify adults as meeting the 23 METs-h/week reference value by using objective measurements. Objectively measured physical activity levels of 1837 Japanese adults aged from 23 - 69 yrs from both urban and rural Japanese cohorts were provided. Amount of physical activity and daily step counts were assessed using a triaxial accelerometer (Actimarker EW4800; Panasonic Electric Works). Receiver operating characteristics (ROC) curve analysis determined the optimal daily step counts (steps/day) that discriminated adults who met the reference value from those who did not. Approximately 48 $\%$ of Japanese adults met the 23 METs-h/week of physical activity reference value. ROC curve analysis found that 9341 steps/day produced $77.1 \%$ of sensitivity and $79.5 \%$ of specificity in all subject. When the analysis was performed in each cohort, 9980 steps/day and 8640 steps/day were indicated as the optimal daily step counts for them to meet $23 \mathrm{METs}-\mathrm{h} /$ week in urban and rural cohort, respectively. These data suggest that Japanese adults are likely to meet $23 \mathrm{METs}-\mathrm{h} /$ week of physical activity reference value if they accumulate between 8500 and 10,000 steps/day of daily step counts.
\end{abstract}

Jpn J Phys Fitness Sports Med, 61(2): 183-191 (2012)

Keywords : Physical activity, Reference value, Health promotion, ROC curve

緒言

身体活動・運動習慣や食習慣などの生活習慣は, 肥満 や生活習慣病の発症に関わっており, 多くの研究に打い て，身体活動・運動を増大させることは，それらの発 症を予防すると報告している ${ }^{1-4)}$ ，さらに，それらを予 防・改善するための身体活動・運動に関するガイドライ ンが, 多くの国や機関から出されておりり ${ }^{5-7)}$ ，日本にお いても，2006年に厚生労働省から「健康づくりのための 運動基準2006」（以下，運動基準）が発表され，健康づ くりのための身体活動量の基準值として週23メッッ・時
が提唱された

日本に扔ける運動基準では, 各運動強度の単位メッッ と時間（時）の積であるメッツ・時を用いて身体活動量 の基準值を示しているが，専門家には受け入れやすいも のの，一般国民には理解が困難な場合が多い，身体活動 量の増大をめざしたポピュレーションアプローチにおい ては，身体活動量の基準值である週23メッッ・時をより 平易な語句に変換し，一般国民が理解しやすい言葉で普 及・啓発させることが必要である，近年では，歩数計を 用いた介入研究の生活習慣病予防の有効性も示されてお

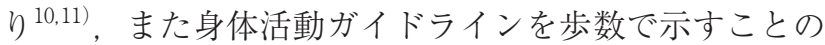


重要性が提唱されている ${ }^{12)}$

欧米においても各国のガイドラインにおいて提唱され ている「中強度の身体活動を少なくとも1日30分」を, 歩数で示す試みが行われてきた ${ }^{13-18)}$. Macfarlaneらは, 15〜55歳の男女 49 名を対象に, 歩数計と加速度計を用 い, 中強度の身体活動30分は，歩数にすると 1 日8000 歩に相当することを示した ${ }^{14)}$ 。また，Adamsらは，子 供を対象に，推奨量である「中強度の身体活動を60分」 に相当する歩数を，ROC曲線を用いて算出すると 1 日 9930歩であることを報告している ${ }^{13)}$. 日本に打いても， Tanakaらにより, 4〜6歳の子供157名を対象に, 中強 度の身体活動60分に対する歩数として 1 日9934歩である ことが示された ${ }^{16)}$. 歩数計は, 質問紙法による身体活動 量評価よりも主観が入りにくく客観性が高い. 歩数計と

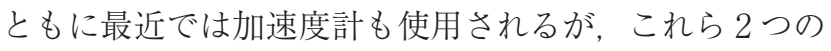
機器のうち, 歩数計はより安価であり, 使用法が簡便で ある ${ }^{19,20)}$. また, 歩数計からの歩数デー夕は, 加速度計 の身体活動量データとよく相関している ${ }^{21)}$. 加えて, 歩 数計を用いた認知行動的介入が身体活動の増加に有効で あることが示されている11)。したがって，運動基準で示 されている身体活動量の基準值である週23メッッ・時を 歩数に変換することは，国民がこの基準を活用する上で 有用であると思われる。

運動基準を国民に広く普及させるための「健康づくり のための運動指針2006<エクササイズガイド2006>」(以 下，エクササイズガイド）では, 週23メッッ・時を歩数 に換算し，1日あたりおよそ8000～10,000歩と推定して いる9). しかしながら, これは, 週23メッッ・時=1日 3.3 メッツ・時が 3 〜 4 メッッの強度の歩行もしくはそ れと同等の身体活動を 1 日あたり 1 時間程度行うのに相 当（10分あたり1000歩とすると，約6000歩に相当）し, これに加えて日常生活で意識されない間欠的な低強度の 歩行による歩数が2000～4000歩であるという推定から示 されたものであり，科学的根拠が不十分であると言わざ るをえない，そこで本研究は，運動基準で示された身体 活動の基準值週23メッッ・時をより平易な指標である歩 数に変換し, 運動基準ならびにエクササイズガイドのさ らなる普及·啓発を促す手だてとすることを目的に行う． また, 地域差や, 肥満者と非肥満者, 若齢者と高齢者と いった集団特性の差が，これらメッッ・時と歩数との関 連に違いをもたらすかについても検討することを目的と した.

\section{研究方法}

対象 本研究の対象者は，東京都を中心としたコホート であるNutrition and Exercise Intervention Study (NEXIS) (ClinicalTrials.gov Identifier : NCT00926744) に登 録されている909名, および, 長野県佐久市を中心とし
たコホートであるSaku Control Obesity Program(SCOP) に登録されている2175名のうち，下記の基準を満たす 1837名を対象とした，NEXISコホートでは，地域住民 への広告や企業等での募集により研究への参加を募り, その参加基準としては運動が禁忌でないものとした。 SCOP ニートに扔いては, 総合病院の人間ドック受診 者を対象に研究参加を募った。両コホート登録者3084名 のうち, 加速度計データが欠損している530名 (17.2\%) を除外した。また自記式の問診票により，現病歴等を聞 き取り, 脳血管疾患, 腎臓病等の重篤な疾患を有する者 $(\mathrm{n}=219$ 名, $7.1 \%)$, 高血圧症, 糖尿病, 脂質異常症の 服薬を行っている者 $(\mathrm{n}=826$ 名, $26.8 \%)$ も除外した. 最終的に23歳から69歳までの男女1837名(NEXIS 773名, SCOP 1064名, 男性848名, 女性989名) を本研究の対象 とした。

本研究を始めるにあたり, 独立行政法人国立健康・栄 養研究所に打ける研究倫理審査委員会の承認を受けた。 また，全ての被験者には，本研究の目的や意義，危険性 について口頭拧よび文章にて説明を行い, 研究参加への 同意を得た。

生活習慣病危険因子の測定 10時間の絶食を行った後, 早朝に身長挹よび体重を測定し, BMI $\left(\mathrm{kg} / \mathrm{m}^{2}\right)$ を算 出した。仰臥位において十分な安静の時間を取った後, form ABI/PWV（オムロンコーリン社製，日本）により 上腕血圧を測定した。 また, 肘正中皮静脈から採血を行っ た，採取した血液を3000 rpmで20分間の遠心分離を行 い, 血清を得た，得られた血清から, 血糖值, 中性脂肪, HDLーコレステロールを測定した.

身体活動量の評価 日常生活における身体活動量（メッ ツ・時）㧍よび歩数は, 3 次元加速度計 (Actimarker EW4800; パナソニック社製，日本）を用いて評価した。 この加速度計には 3 軸方向 $(\mathrm{x}$ : 上下, $\mathrm{y}$ : 左右, $\mathrm{z}$ : 前後) の加速度センサーが内蔵されており, 各軸方向の加速度 を合成した加速度值が算出された ${ }^{22}$. 活動強度は, 3 軸 の合成加速度の標準偏差によって算出され， 1 分毎の加 速度值 $(\mathrm{Km})$ は以下の式で算出された。

\section{$K \mathrm{~m}=\sqrt{\frac{1}{\mathrm{n}-1}\left[\left(\sum_{k=1}^{\mathrm{n}} \mathrm{x}_{\mathrm{i}}^{2}+\sum_{k=1}^{\mathrm{n}} \mathrm{y}_{\mathrm{i}}^{2}+\sum_{k=1}^{\mathrm{n}} \mathrm{z}_{\mathrm{i}}^{2}\right)-\frac{1}{\mathrm{n}}\left\{\left(\sum_{k=1}^{\mathrm{n}} \mathrm{x}_{\mathrm{i}}\right)^{2}+\left(\sum_{k=1}^{\mathrm{n}} \mathrm{y}_{\mathrm{i}}\right)^{2}+\left(\sum_{k=1}^{\mathrm{n}} \mathrm{z}_{\mathrm{i}}\right)^{2}\right\}\right]}$}

xi，yi，ziは1分毎に扔ける各軸方向の加速度を示し ており, $\mathrm{n} は 1$ 分間にサンプリングされる個数である. 加速度值のサンプリング周波数は $20 \mathrm{~Hz}$ であり, 算出さ れた加速度值は内蔵されたアルゴリズムによってメッッ に変換され，1分毎に平均した值が時刻暦とともに内蔵 メモリに蓄積された。この 3 次元加速度計は，それによ り得られた身体活動量が， 7 種類の家事作業と 7 水準の 
歩行におけるダグラスバックを用いて得られた酸素摂取 量との間に高い相関 $(r=0.93)$ が認められており，また， 二重標識水法によって測定された総消費エネルギーとの 間にも高い相関（ $\mathrm{r}=0.84 ）$ が認められており，妥当性が 検証されたものである23).

被験者は，起床から就寝までの間，水泳や入浴のよう な水中での活動以外において, 3 次元加速度計を腰部に 装着した。また，同時に身体活動の簡易な 1 日毎の欄を 設けた記録用紙にて，その日が非日常的活動を伴ったか 否か，また非装着時間の有無について記録した。非日常 的活動を伴ったか否かについては，“装着期間中に，非 日常的な出来事（怪我をした，風邪を引いて寝込んだ, 旅行に行った）があれば特記事項の闌にご記入下さい. 毎月旅行に行くなど, 定期的な事柄については記入頂か なくても結構です”とし, 非装着時間の有無については, “機器の着け忘れや諸事情により，活動をしていたにも かかわらず, 機器を装着しなかった時間がありましたら, その時刻を記入してくたさい”とした。この身体活動記 録を元に，非日常的活動を伴った日および非装着時間が あった日を除外した。さらに，3 次元加速度計に記録さ れた1.1METs以上の加速度データが 6 時間以上認めら れる日を採用し，6時間に到達しない日を除外した。 こ の基準を用いることで, 加速度計の有効日として先行研 究において多く採用されている基準である装着時間10時 間以上 ${ }^{24)}$ を満たしている日数は93.5\%に達することを本 研究の被験者から抽出した24名のデータにおいて確認し た。

本研究において装着した28日間のうち, 上記基準を満 たす日を全て有効日とし，平日および休日を含む14日以 上28日以下の日数において，3メッッ以上の強度におけ る身体活動量（メッツ・時）（以下, 中高強度身体活動量） および歩数の 1 日あたりの平均值を算出した，有効日が 14日未満の場合には, 有効日が14日を超えるよう再度装 着を依頼した。 7 日以上の歩数のデータが1 1 月間の身 体活動量を評価することが可能であると報告されている ため ${ }^{25)}$ ，14日以上の装着期間は，1 1 月月間の身体活動を 評価していると考えられる。また，1 日における 3 メッ ツ以上の中高強度身体活動に費やした時間についても算 出した。中高強度身体活動量については, 運動基準の週 $23 \times ッ ッ ・$ 時と比較するため, 得られた 1 日あたりの中 高強度身体活動量（メッツ・時）から週あたりの中高強
度身体活動量（メッツ・時/週）を求めた。この週あた りの中高強度身体活動量が23メッツ・時以上の者を運動 基準達成者，23メッツ・時未満の者を運動基準未達成者 とした。

統計解析 性別や地域における年齢や体組成, 生活習慣 病危険因子, 身体活動量の比較には, 対応のないt-test を用いた。またコホートにおける男女の度数を比較する ために， $\chi^{2}$ 検定を行った。中強度身体活動量と 1 日あ たりの歩数との相関関係は, Pearsonの相関係数の検定 により行い, 週あたりのメッツ・時と 1 日あたりの歩数 との関係については直線回帰分析により検討した。運 動基準である週23メッツ・時に相当する1日あたりの 歩数を検出するため, 受診者動作特異性曲線 (Receiver Operating Characteristic curve: 以下ROC曲線）を用い て検討した。連続的な任意の歩数における週23メッッ・ 時に対する感度および特異度を求め, ROC曲線を作成 し, AUC (area under curve) を獲得した。 ROC曲線 の左肩ポイント（感度 $=1,1-$ 特異度 $=0$ ）に最も近い 距離にある值を求め, これをカットオフ歩数とした。左 肩に最も近い距離は, $(1-\text { 感度 })^{2}+(1-\text { 特異度 })^{2}$ の最 小值とした. 得られたカットオフ歩数における週23メッ ツ・時に対する感度と特異度, 陽性および陰性反応適中 度を求め, そのカットオフ歩数の妥当性を検討した。

結果は, 平均值土標準偏差で示し，有意水準は危険 率 $5 \%$ 未満とした。解析にはSPSS 16.0 (SPSS Japan社, 日本）を用いて行った。

\section{研究結果}

被験者特性 対象者の性年代別の構成を表 1 に示した。 平均年齢は53.0 19.9 歳であった。男性の平均年齢は5 2.6 \pm 10.2 歳で, 女性は53.2 \pm 9.7 歳であり，男女において年 齢に差は認められなかった。また対象者の勤務形態につ いて，NEXISに関しては不明であるが，SCOPに関して 常勤・自営業が $63.9 \%$ と半数以上を占め, 臨時・パート が7.1\%，農業が7.1\%，主婦・無職が21.8\%だった。また， 農業への従事の有無について聞いたところ $37.1 \%$ 対象 者が従事していた。本研究における被験者特性を表 2 に示した。生活習慣病危険因子においては, BMI，血糖 值, 中性脂肪, 血圧が男性において有意に高い值であり, HDLコレステロールが女性において有意に高い值を示

Table 1. Numbers of participants by gender and age groups

\begin{tabular}{ccccccc}
\hline & \multicolumn{5}{c}{ age } & \\
\cline { 2 - 5 } & $20-29$ & $30-39$ & $40-49$ & $50-59$ & $60-69$ & Total \\
\hline \hline Male & 5 & 107 & 183 & 309 & 244 & 848 \\
& $0.6 \%$ & $12.6 \%$ & $21.6 \%$ & $36.4 \%$ & $28.8 \%$ & $100 \%$ \\
Female & 5 & 109 & 195 & 375 & 305 & 989 \\
& $0.5 \%$ & $11.0 \%$ & $19.7 \%$ & $37.9 \%$ & $30.8 \%$ & $100 \%$ \\
\hline
\end{tabular}


Table 2. The subjects characteristics according to the sex and the cohort

\begin{tabular}{|c|c|c|c|c|c|}
\hline & Total & Male & Female & NEXIS & SCOP \\
\hline $\mathrm{N}$ & 1837 & 848 & 989 & $773(246 / 527)$ & $1064(602 / 462)$ \\
\hline age & $53.0 \pm 9.9$ & $52.6 \pm 10.2$ & $53.2 \pm 9.7$ & $48.8 \pm 10.4$ & $55.9 \pm 8.4 \#$ \\
\hline Hight (cm) & $162.7 \pm 8.4$ & $169.4 \pm 5.9$ & $157.0 \pm 5.6 *$ & $161.3 \pm 8.3$ & $163.7 \pm 8.4 \#$ \\
\hline Weight (kg) & $60.2 \pm 11.0$ & $67.3 \pm 9.8$ & $54.1 \pm 7.8 *$ & $59.0 \pm 10.9$ & $61.1 \pm 10.9 \#$ \\
\hline Waist circumstance $(\mathrm{cm})$ & $81.5 \pm 8.6$ & $83.8 \pm 7.8$ & $79.6 \pm 8.9 *$ & $80.8 \pm 9.2$ & $82.0 \pm 8.2 \#$ \\
\hline BMI & $22.6 \pm 3.0$ & $23.4 \pm 2.9$ & $22.0 \pm 3.0 *$ & $22.6 \pm 3.2$ & $22.7 \pm 2.9$ \\
\hline Fasting blood glucose (mg/dL) & $95.4 \pm 12.8$ & $98.4 \pm 13.6$ & $93.0 \pm 11.5 *$ & $90.3 \pm 10.8$ & $99.2 \pm 12.9 \#$ \\
\hline HDL choresterol (mg/dL) & $62.4 \pm 15.2$ & $56.7 \pm 14.1$ & $66.9 \pm 14.6 *$ & $64.2 \pm 15.6$ & $60.6 \pm 14.7 \#$ \\
\hline Trigricerol (mg/dL) & $100.0 \pm 65.8$ & $118.2 \pm 78.4$ & $84.3 \pm 47.2 *$ & $89.3 \pm 55.4$ & $107.7 \pm 71.4 \#$ \\
\hline $\mathrm{SBP}(\mathrm{mmHg})$ & $116.7 \pm 14.7$ & $119.8 \pm 13.7$ & $114.1 \pm 14.9 *$ & $117.2 \pm 14.6$ & $116.4 \pm 14.7$ \\
\hline $\mathrm{DBP}(\mathrm{mmHg})$ & $71.1 \pm 10.4$ & $74.6 \pm 9.9$ & $68.0 \pm 9.8 *$ & $71.2 \pm 10.1$ & $71.0 \pm 10.6$ \\
\hline Daily step counts (steps/day) & $9564 \pm 3540$ & $9594 \pm 3630$ & $9537 \pm 3463$ & $10517 \pm 3691$ & $8871 \pm 3257 \#$ \\
\hline Amount of MVPA (METs-h/week) & $25.0 \pm 14.7$ & $24.8 \pm 16.4$ & $25.2 \pm 13.1$ & $26.7 \pm 14.5$ & $23.8 \pm 14.7 \#$ \\
\hline
\end{tabular}

MVPA: moderate and vigrous physical activity

*: $\mathrm{P}<0.05$, Male vs Female

\#: $\mathrm{P}<0.05$, NEXIS vs SCOP

した。いずれの生活習慣病危険因子においても，全被験 者の平均值は基準值の範囲内にあった。

日常生活における身体活動量 本研究における全被験者 の平均歩数は 1 日あたり $9564 \pm 3540$ 歩（男性9594 \pm 3630 歩, 女性9537 \pm 3463 歩）であり，中高強度身体活動量

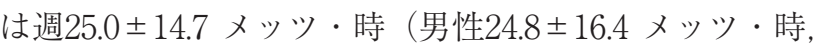
女性25.2 13.1 メッツ・時）であった（表 2$)$ 。これは， 平成21年に発表された国民健康・栄養調査の平均歩数 を（男性7214歩，女性6352歩）大きく上回っており，本 研究の被験者は身体活動量の高い集団であると考えられ る。また，NEXISとSCOPにおいて，歩数および中高強 度身体活動量を比較すると，歩数は，それぞれ10517士 3691 歩と8871 \pm 3257 歩であり $(\mathrm{p}<0.01)$, 中高強度身体 活動量においては, 週26.7 14.5 メッツ・時と週23.8 14.7 メッツ・時で，両指標ともNEXISの被験者の方が 有意に高い值であった（ $\mathrm{p}<0.01 ） （$ 表 $2 ）$.

週あたりの中高強度身体活動量と 1 日あたりの歩数 との間には，有意な正の相関が認められた（ $r=0.743$, $\mathrm{p}<0.01)$. 中高強度身体活動量の基準值である週23メッ ツ・時を達成している被験者の割合は，47.8\%（男性 42.8\%，女性52.2\%，男性vs女性：p<0.01）であった。

週23メッツ・時と歩数との関係 本研究では, 週23メッ ツ・時に相当する 1 日あたりの歩数を決定するため, ROC曲線を用いてカットオフ歩数を求め, その歩数を 用いた際の週23メッツ・時に対する感度および特異度, 陽性および陰性反応適中度から妥当性を考慮した。全 被験者におけるROC曲線を図 1 に示した。AUCは0.862 (95\%信頼区間： 0.845 - 0.878）であり（p<0.01）, カッ トオフ值として9341歩が決定された。この9341歩におけ る感度は77.1\%，特異度79.5\%，陽性反応適中度77.6\%,
陰性反応適中度79.1\%であった（表 3 ）。さらに，運動基 準の週23メッッ・時は，1日において 3 メッツ以上の中 高強度身体活動量をどのくらいの時間行うことに相当す るかを検討するため，全被験者を対象にROC曲線によ り求めたところ，1 日あたり54分というカットオフポイ ントが得られた。

また，地域差や集団の特性の差が，週23メッツ・時に 相当する歩数に違いをもたらすかを検討した。コホート 別に，週23メッツ・時に相当する歩数をROC曲線によ り求めたところ，NEXISで 9980 歩（感度76.2\%, 特異度 80.9\%), SCOPで8640歩（感度79.2\%，特異度76.5\%）で あった。男女別では，男性で9414歩（感度 $80.2 \%$, 特異 度80.0\%)，女性で9188歩（感度77.3\%，特異度77.4\%）で あった。さらに，本被験者を年齢により 3 分位（49歳以 下，50-58歳，59歳以上）に分類し，カットオフ歩数を 求めた。3分位に分ける際，同年齢が多く存在しており

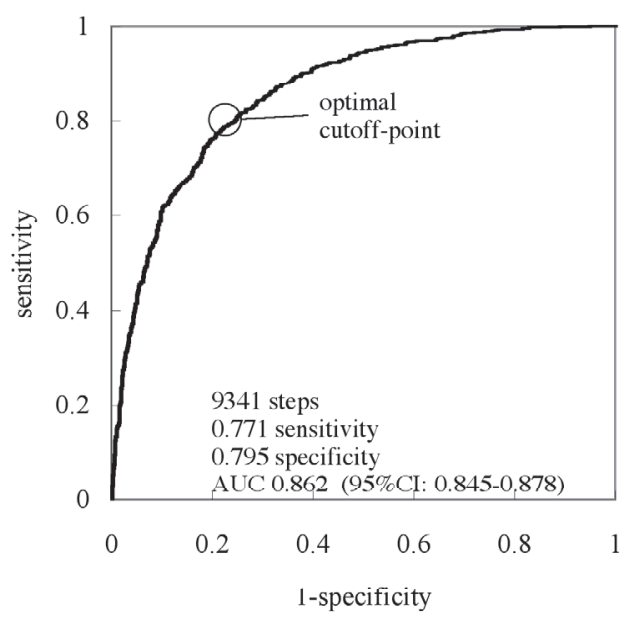

Fig 1. Receiver operating characteristic (ROC) curves showing the optimal daily step counts cutoff point for 23 METs-h/week of amount of moderate and vigorous physical activity 
Table 3. Daily step counts cutoff points to identify 23METs-h/week of amount of physical acvitivy by ROC analysis.

\begin{tabular}{|c|c|c|c|c|c|c|c|}
\hline Category & $\mathrm{n}$ & Cutoff point & AUC $(95 \% \mathrm{CI})$ & $\mathrm{Se}(\%)$ & $\mathrm{Sp}(\%)$ & $+\mathrm{PV}(\%)$ & -PV $(\%)$ \\
\hline All subjects & 1837 & 9341 & $0.862(0.845-0.878)$ & 77.1 & 79.5 & 77.6 & 79.1 \\
\hline \multicolumn{8}{|l|}{ Cohorts } \\
\hline NEXIS & 773 & 9980 & $0.860(0.834-0.887)$ & 76.2 & 80.9 & 83.5 & 72.8 \\
\hline SCOP & 1064 & 8640 & $0.855(0.833-0.877)$ & 79.2 & 76.5 & 70.9 & 83.5 \\
\hline \multicolumn{8}{|l|}{ sex } \\
\hline male & 848 & 9414 & $0.879(0.856-0.902)$ & 80.2 & 80.0 & 75.0 & 84.3 \\
\hline female & 989 & 9188 & $0.851(0.828-0.875)$ & 77.3 & 77.4 & 78.9 & 75.8 \\
\hline \multicolumn{8}{|l|}{ age } \\
\hline$\sim 49$ & 604 & 9434 & $0.879(0.852-0.906)$ & 81.4 & 79.9 & 79.5 & 81.8 \\
\hline $50-58$ & 603 & 9187 & $0.854(0.824-0.884)$ & 78.0 & 77.7 & 71.7 & 82.9 \\
\hline $59 \sim$ & 630 & 9296 & $0.855(0.825-0.884)$ & 75.2 & 81.7 & 81.8 & 74.9 \\
\hline \multicolumn{8}{|l|}{ BMI } \\
\hline$<18.5$ & 101 & 8865 & $0.826(0.745-0.906)$ & 80.8 & 77.6 & 79.2 & 79.2 \\
\hline $18.5-25$ & 1391 & 9341 & $0.861(0.841-0.880)$ & 78.4 & 79.0 & 78.4 & 79.0 \\
\hline $25=<$ & 345 & 9004 & $0.873(0.837-0.909)$ & 77.5 & 78.3 & 71.4 & 83.2 \\
\hline
\end{tabular}

AUC, area under the ROC curve; Se, Sensitivity; Sp, Specificity; +PV, positive Predictive value; -PV, negative predictive value

均等に人数を分類することが出来なかったため, 人数が 最も 3 分位に近似する年齢により分類した.49歳以下の 群で9434歩（感度81.4\%，特異度79.9\%)，50-58歳の群 で9187歩（感度78.0\%，特異度77.7\%)，59歳以上の群で 9296歩（感度75.2\%, 特異度81.7\%）であった。BMIでは, BMIが18.5未満においては8865歩（感度 $80.8 \%$, 特異度 $77.6 \%$ ）, 18.5以上かつ25未満では9341歩（感度78.4\%, 特異度79.0\%)，25以上に扔いては，9004歩（感度77.5\%, 特異度78.3\%) であった。

また，週あたりのメッッ・時と 1 日あたりの歩数との 回帰分析から週 23 メッッ・時に相当する歩数を求めた。 独立変数に中高強度身体活動量 (メッツ・時/週), 従属 変数に歩数（歩/日）を取り, 回帰直線を引いたところ, 全被験者に扮いて $\mathrm{y}=179 \mathrm{x}-5090$ の式が得られ（図 2) $(p<0.05)$ ，週23メッッ・時に相当する歩数は9206歩であっ た. ROC曲線の検討と同様, コホート別, 性別, 年齢別,

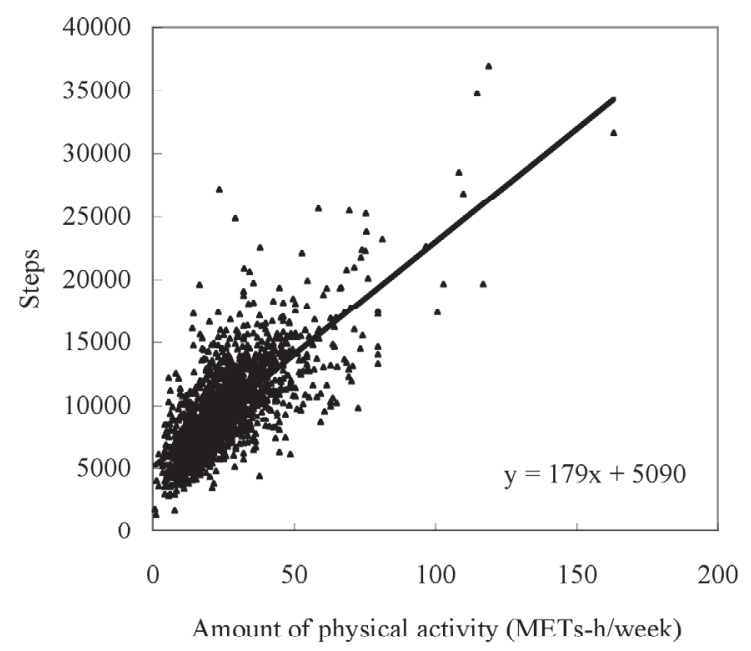

Fig 2. Relationship between amount of moderate and vigorous physical activity (METs-h/week) and daily step counts
BMI別にも検討を行った（表 4).コホート別に見ると， NEXISでは9809歩, SCOPでは8746歩だった。

さらに欧米において身体活動量の基準となっている $「$ 中強度以上の身体活動を 1 日30分以上」について, 中 強度の身体活動を 3 メッッ以上と定義し, ROC曲線に より歩数を算出したところ, 7709歩（感度 $76.9 \%$, 特異 度59.0\%)であった。

\section{考察}

本研究において, 23歳から69歳までの健康な男女 1837 名を対象に，運動基準で提唱された身体活動量の基準值 である週23メッッ・時に相当する歩数を検討したところ 9341歩であることが推計された。コホート別に見ると 東京都を中心とするコホートであるNEXISにおいては 9980歩であり，長野県佐久市を中心とするコホートであ るSCOPにおいては8640歩であった。東京都と長野県と

Table 4. The regression analysis for daily step counts corresponding to $23 \mathrm{METs}$-h/week of amount of physical activity

\begin{tabular}{lccll}
\hline \multicolumn{1}{c}{ Category } & $\mathrm{n}$ & & Equation & Steps \\
\hline \hline $\begin{array}{l}\text { All subjects } \\
\text { Cohort }\end{array}$ & 1837 & $\mathrm{y}=$ & $179 \mathrm{x}+5090$ & 9206 \\
$\quad$ & & & \\
$\quad$ NEXIS & 773 & $\mathrm{y}=$ & $191 \mathrm{x}+5406$ & 9809 \\
$\quad$ SCOP & 1064 & $\mathrm{y}=$ & $164 \mathrm{x}+4982$ & 8746 \\
sex & & & & \\
$\quad$ male & 848 & $\mathrm{y}=$ & $160 \mathrm{x}+5623$ & 9308 \\
$\quad$ female & 989 & $\mathrm{y}=$ & $204 \mathrm{x}+4399$ & 9092 \\
age & & & & \\
$\sim 50$ & 604 & $\mathrm{y}=$ & $170 \mathrm{x}+5455$ & 9361 \\
$\quad 51-60$ & 603 & $\mathrm{y}=180 \mathrm{x}+5104$ & 9253 \\
$\quad 61 \sim$ & 630 & $\mathrm{y}=191 \mathrm{x}+4616$ & 9013 \\
BMI & & & & \\
$<18.5$ & 101 & $\mathrm{y}=$ & $167 \mathrm{x}+5343$ & 9194 \\
$18.5-25$ & 1391 & $\mathrm{y}=$ & $181 \mathrm{x}+5048$ & 9216 \\
$25=<$ & 345 & $\mathrm{y}=$ & $174 \mathrm{x}+5150$ & 9158 \\
\hline
\end{tabular}


いう地域の差により，週23メッッ・時を達成するため の歩数に1340歩の差が認められた。 また, 性別や年齢, BMIによる分類において, 週23メッッ・時に相当する歩 数には差が認められたものの, その差は約220４80歩で あり，地域による差より小さかった，ROC曲線によっ て求めた歩数のカットオフポイントは, 回帰直線により 算出した歩数と同様の傾向を示した，本研究では，地域 別, 集団属性別で見た場合, そのカットオフ歩数は 1 日 8640歩〜9980歩の範囲に分布した. したがって, 週23メッ ッ・時に相当する歩数は，打打よそ 1 日8500 10,000歩 と表現するのが妥当であると考えられる。この知見は, エクササイズガイドに扔いて推奨されている歩数である 1日8000歩〜10,000歩とほぼ一致しており，その妥当性 を支持するものであった。

我々の研究以前に, ガイドラインで提示されている身 体活動の推奨量を歩数で示すことを試みた研究がいくつ か行われてきている.100歩/分のペースでの歩行が，お およそ 3 メッツでの強度の通常歩行であることがよく知 られており ${ }^{26)}$ ，中強度以上の身体活動30分は，3000歩〜 4000歩に直接的に歩数に変換可能なことが示唆されてい る ${ }^{18,26-28)}$. 米国の身体活動ガイドラインでは,「中強度 以上の身体活動を少なくとも1日あたり30分」といった 推奨量が提唱されているが, Macfarlaneら ${ }^{14)}$ は, 中強度 以上の身体活動 1 日30分は 1 日8000歩に相当することを 報告している。本研究に扔いて, 中高強度身体活動30分 に相当する歩数を算出したところ，1 日7709歩という結 果が得られた。これはMacfarlaneら ${ }^{14)}$ と比較して若干低 い值であった。 その理由として, 歩数や活動量算出の感 度やアルゴリズムの違いや研究対象の民族ならびに生活 環境の違いなどが推察される。また, 本研究に抢いて「中 強度以上の身体活動30分」を算出する際，米国の「10分 以上の継続する活動のみを30分に含める」という概念は 考慮されていない。したがって,「中強度以上の身体活 動30分」の基準達成の判断が緩くなり, カットオフ歩数 を求めた際，その歩数が低くなっている可能性が考えら れる。

Bassett et al. ${ }^{29)}$ によると，米国に打ける成人の歩数は 男性が5340歩，女性が4912歩であると報告されている。 米国の「中強度以上の身体活動を少なくとも 1 日あた り30分」といった身体活動の推奨量は約8000歩に相当 し14,17)，米国の歩数の現状より約2500歩〜3000歩ほど多 い. 一方, 我が国の国民健康・栄養調査の結果では男性 が7321歩, 女性が6267歩であり ${ }^{30)}$, 米国と比較して歩数 が多いことが報告されている。運動基準である週23メッ ッ・時は, 本研究に打いて8500歩〜10,000歩に相当し, 我が国の歩数の現状よりも2500歩〜3500歩ほど多い，米 国も我が国も，各国民の身体活動の現状より同程度多い 基準を設定していることは興味深い。このことと，身
体活動と生活習慣病リスクの低減との間に量反応関係が ある ${ }^{4)}$ こを考え併せると，本研究により得られた週23 メッッ・時に相当する 1 日当たりの歩数 8500 歩〜 10,000 歩は, 日本国民が生活習慣病予防の目的に目指すべき歩 数として妥当であると思われる。

都心部と農村部において歩数や身体活動量を比較した 研究では，都市部に扔いて歩数が多く31)，また身体活動 ガイドラインの基準值に達しているものが多い32) ことが 報告されている，一方で，これまで一歩あたりの強度と いった“身体活動の質”に関して地域による差があるか を検討した研究は行われていない，本研究では，コホー 卜や性，年齢，BMIによる集団特性の差が，カットオフ 歩数に違いをもたらすかを検証した。 その結果，性，年 齢，BMIに拈いては大きな差は見られなかったが，2つ のコホートの間に約1340歩の差が認められた。週あたり の中高強度身体活動量および歩数を比較すると, 東京を 中心としたNEXISで有意に高いものの，カットオフ歩 数は高值を示している. これらカットオフ歩数における 地域差は，通勤形態の違いや農業従事の有無などの“身 体活動の質”の差が影響を及ぼしている可能性が考えら れる.ささら にark et $\mathrm{al}^{33}$ によると, 本研究において使 用した 3 次元加速度計は, $55 \mathrm{~m} /$ 分 $=3.3 \mathrm{~km} /$ 時程度の 遅い歩行速度に扔いて歩数を有意に過小評価することが 報告された。したがって，歩行速度の遅い集団を含む場 合，週23メッッ・時に相当する歩数が低く見積もられる かもしれない。一方, 男女や若齢者と高齢者, 非肥満者 と肥満者に抢いて, 週23メッッ・時に相当する歩数には 地域差のような差が認められなかった。本研究において 週23メッツ・時に相当する歩数に差が生じなかった理由 については, 脳血管疾患, 腎臓病等の重篤な疾患を有す る者や高血圧症，糖尿病，脂質異常症の服薬を行ってい る者が除外され，比較的健康な被験者であることが考元 られる。

本研究において, 59歳以上を対象とした場合の週23 メッッ・時に相当する歩数は9296歩であることが推計さ れた，平成21年度の国民健康・栄養調査に打ける歩数 は，60-69歳に扔いて男性で6949歩，女性で6381歩であ り，70歳以上に打いて男性で4707歩，女性で3797歩であ る. 本研究の60-69歳の対象者に扮ける歩数は, 男性に 扔いて平均 $9741 \pm 3434$ 歩であり, 女性で $9224 \pm 3393$ 歩で あり，国民健康・栄養調査と比較して歩数が多い集団で ある。したがって, 本研究で示された59歳以上を対象と した際の週23メッッ・時に相当する歩数9296歩は日本国 民における59歳以上の集団で達成可能か否かを十分考慮 する必要があると思われる。

週23メッッ・時が，3メッッ以上の中高強度身体活動 量を 1 日あたりどのくらいの時間行うことに相当するか を検討した結果，1日あたり54分というカットオフポイ 
ントが得られた，米国の身体活動ガイドライン「中強度 以上の身体活動30分」と比較して, 長い時間が示された が，これには上述したカットオフ歩数と同様，「10分以 上の継続」が考慮されていないことや，基準値策定のた めの論文の採択基準が異なることなどが考えられ，日本 に扔いて示されている週23メッッ・時という基準と単純 に比較することはできず, 慎重な解釈が必要である。し かしながら, Masurier et al. ${ }^{34)}$ は 1 日10,000歩以上を達 成しているグループの 1 日あたりの中強度身体活動の時 間を算出したところ，「10分以上の継続」が考慮されて いない場合に打いては62.1 27.7 分,「10分以上の継続」 を考慮した場合には30.1 21.0 分であったことを報告し ている，本研究に打ける週23メッッ・時は9341歩であり, 「10分以上の継続」を考慮しない中高強度身体活動時間 の54分は概ね妥当な数值であると思われる.

本研究には，いくつかの限界が存在する。まず 1 点目 は, 本研究において使用した 3 次元加速度計の歩数の正 確性についてである。先に述べたようにPark et al ${ }^{33)}$ は, 本研究に打いて使用した 3 次元加速度計は, $55 \mathrm{~m} /$ 分 $=$ $3.3 \mathrm{~km} /$ 時程度のゆっくりとした歩行速度において歩数 を有意に過小評価することを報告している。したがって, ゆっくりとした活動が多い集団に打いては，活動が歩行 として認識されて扔らず，週23メッッ・時に相当する歩 数を少なく見積もる可能性が考えられる．2 点目は使用 する加速度計の違いに関してである。加速度計を使用し て身体活動量の基準值に相当する歩数を求めようとする 際, 各加速度計に打ける歩数への变換に扔ける感受性や 身体活動量評価のアルゴリズムに器差があるため ${ }^{35)}$ ，こ れらがカットオフ歩数に影響を及ぼす可能性が考えられ る。最後に, 集団に打ける差異についても考慮する必要 があると思われる，本研究では，NEXIS拉よびSCOPに 扔いて $2 つ の$ 集団を対象としたが，それら対象により カットオフ歩数には1340歩の差が認められ, 異なる集団 を対象にした際には，これらカットオフ歩数に差異が生 じる可能性がある。 Tudor-Lockeら ${ }^{36)}$ は, 推奨值や基準 值に対する歩数は, 地域や属性で異なっており, それら を含む範囲で提唱することが良いとしている，本研究の 3 つの限界を考慮すると, 週 23 メッッ・時に相当する歩 数は，扔扮よそ1 日8500～10,000歩に相当するというよ うに範囲を持って表現するのが妥当であろう.

我が国は歩数計が古くから普及して扮り，1960年代 以降の万歩計という言葉に象徵されると㧍り1日あた り10,000歩を基準に歩くことが“経験的に”推奨されてき た36)。また,「すこやか生活習慣国民運動」のような厚 生労働省の最近の健康づくりのためのポピュレーション アプローチに打いて，「まず1000歩増やしてみよう」と いった歩数に焦点を当てたスローガンが揭げられてい る37)。さらに, 最近では普及率が93\%となった携带電話
に ${ }^{38)}$, 加速度センサーを活用した歩数計機能が搭載され, 多くの国民が歩数を知ることが出来る環境が整ってきて いる. このような歴史的, 社会的背景から, 学問的には メッッ・時などの単位で表現される身体活動量の概念を より平易で日本人になじみの深い歩数に換言すること は，身体活動に関する認知を高めること，エクササイズ ガイドの普及・啓発，ひいては日本人の身体活動量増大 のために，有効であると思われる．

\section{結 論}

本研究では,「健康づくりのための運動基準2006」で 示された身体活動量の基準值である週23メッッ・時に相 当する歩数を，23歳から69歳までの健康な男女1837名に おいて検証した。その結果, 全被験者に扔ける週23メッ ッ・時に相当する歩数は，1 日9341歩であった。また地 域別や集団の特性別に検討した結果，週23メッッ・時に 相当する歩数は1日8640歩〜9980歩の範囲に分布した. 以上の結果から, 週23メッッ・時の中強度以上の身体活 動量に相当する歩数は，打扔よそ1日8500～10,000歩に 相当することが示唆された。

\section{引用文 献}

1) Helmrich SP, Ragland DR, Leung RW, and Paffenbarger RS, Jr. Physical activity and reduced occurrence of non-insulin-dependent diabetes mellitus. $N$ Engl $J$ Med 325: 147-152, 1991.

2) Okada K, Hayashi T, Tsumura K, Suematsu C, Endo G, and Fujii S. Leisure-time physical activity at weekends and the risk of Type 2 diabetes mellitus in Japanese men: the Osaka Health Survey. Diabet Med 17: 53-58, 2000.

3) Hu G, Barengo NC, Tuomilehto J, Lakka TA, Nissinen A, and Jousilahti P. Relationship of physical activity and body mass index to the risk of hypertension: a prospective study in Finland. Hypertension 43: 25-30, 2004.

4) Zheng H, Orsini N, Amin J, Wolk A, Nguyen VT, and Ehrlich F. Quantifying the dose-response of walking in reducing coronary heart disease risk: meta-analysis. Eur J Epidemiol 24: 181-192, 2009.

5) Organization WH. Global recommendations on physical activity for health. http://www.who.int/dietphysicalactivity/factsheet_recommendations/en/index.html. 2010.

6) Haskell WL, Lee IM, Pate RR, Powell KE, Blair SN, Franklin BA, Macera CA, Heath GW, Thompson PD, and Bauman A. Physical activity and public health: updated recommendation for adults from the American College of Sports Medicine and the American Heart Association. Med Sci Sports Exerc 39: 1423-1434, 2007.

7) Nelson ME, Rejeski WJ, Blair SN, Duncan PW, Judge JO, King AC, Macera CA, and Castaneda-Sceppa C. Physical activity and public health in older adults: recommendation from the American College of Sports Medicine and the American Heart Association. Med 
Sci Sports Exerc 39: 1435-1445, 2007.

8）厚生労働省運動所要量 - 運動指針の策定検討会. 健康 づくりのための運動基準2006～身体活動・運動・体力〜. http://www.mhlw.go.jp/bunya/kenkou/undou02/pdf/ data.pdf. 2006.

9）厚生労働省運動所要量 - 運動指針の策定検討会. 健康 づくりのための運動指針2006〜生活習慣病予防のため に〜<エクササイズガイド2006>. http://www.mhlw. go.jp/bunya/kenkou/undou01/pdf/data.pdf. 2006.

10) Richardson CR, Newton TL, Abraham JJ, Sen A, Jimbo M, and Swartz AM. A meta-analysis of pedometer-based walking interventions and weight loss. Ann Fam Med 6: 69-77, 2008.

11) Bravata DM, Smith-Spangler C, Sundaram V, Gienger AL, Lin N, Lewis R, Stave CD, Olkin I, and Sirard JR. Using pedometers to increase physical activity and improve health: a systematic review. Jama 298: 22962304, 2007.

12) Tudor-Locke C, Craig CL, Brown WJ, Clemes SA, De Cocker K, Giles-Corti B, Hatano Y, Inoue S, Matsudo SM, Mutrie N, Oppert JM, Rowe DA, Schmidt MD, Schofield GM, Spence JC, Teixeira PJ, Tully MA, and Blair SN. How Many Steps/day are Enough? For Adults. Int J Behav Nutr Phys Act 8: 79, 2011.

13) Adams MA, Caparosa S, Thompson S, and Norman GJ. Translating physical activity recommendations for overweight adolescents to steps per day. Am J Prev Med 37: 137-140, 2009.

14) Macfarlane DJ, Chan D, Chan KL, Ho EY, and Lee CC. Using three objective criteria to examine pedometer guidelines for free-living individuals. Eur J Appl Physiol 104: 435-444, 2008.

15) Marshall SJ, Levy SS, Tudor-Locke CE, Kolkhorst FW, Wooten KM, Ji M, Macera CA, and Ainsworth BE. Translating physical activity recommendations into a pedometer-based step goal: 3000 steps in 30 minutes. Am J Prev Med 36: 410-415, 2009.

16) Tanaka $C$ and Tanaka $S$. Daily physical activity in japanese preschool children evaluated by triaxial accelerometry: the relationship between period of engagement in moderate-to-vigorous physical activity and daily step counts. J Physiol Anthropol 28: 283-288, 2009.

17) Tudor-Locke C, Ainsworth BE, Thompson RW, and Matthews CE. Comparison of pedometer and accelerometer measures of free-living physical activity. Med Sci Sports Exerc 34: 2045-2051, 2002.

18) Wilde BE, Sidman CL, and Corbin CB. A 10,000-step count as a physical activity target for sedentary women. Res Q Exerc Sport 72: 411-414, 2001.

19) Freedson PS and Miller K. Objective monitoring of physical activity using motion sensors and heart rate. Res Q Exerc Sport 71: S21-29, 2000.

20) Tudor-Locke CE and Myers AM. Challenges and opportunities for measuring physical activity in sedentary adults. Sports Med 31: 91-100, 2001.

21) Tudor-Locke C, Williams JE, Reis JP, and Pluto D. Utility of pedometers for assessing physical activity: convergent validity. Sports Med 32: 795-808, 2002.

22）松村吉浩, 山本松樹, 北堂正晴, 中村秀樹, 木寺和憲, and 藤本繁夫. 3 軸加速度センサを用いた高精度身体活動量 計. 松下電工技報 56: 60-66, 2008.

23) Yamada Y, Yokoyama K, Noriyasu R, Osaki T, Adachi T, Itoi A, Naito Y, Morimoto T, Kimura M, and Oda S. Light-intensity activities are important for estimating physical activity energy expenditure using uniaxial and triaxial accelerometers. Eur J Appl Physiol 105: 141-152, 2009.

24) Masse LC, Fuemmeler BF, Anderson CB, Matthews CE, Trost SG, Catellier DJ, and Treuth M. Accelerometer data reduction: a comparison of four reduction algorithms on select outcome variables. Med Sci Sports Exerc 37: S544-554, 2005.

25) Clemes SA and Griffiths PL. How many days of pedometer monitoring predict monthly ambulatory activity in adults? Med Sci Sports Exerc 40: 1589-1595, 2008.

26) Tudor-Locke C, Sisson SB, Collova T, Lee SM, and Swan PD. Pedometer-determined step count guidelines for classifying walking intensity in a young ostensibly healthy population. Can J Appl Physiol 30: 666676, 2005

27) Tudor-Locke C, Jones R, Myers AM, Paterson DH, and Ecclestone NA. Contribution of structured exercise class participation and informal walking for exercise to daily physical activity in community-dwelling older adults. Res Q Exerc Sport 73: 350-356, 2002.

28) Welk GJ, Differding JA, Thompson RW, Blair SN, Dziura J, and Hart P. The utility of the Digi-walker step counter to assess daily physical activity patterns. Med Sci Sports Exerc 32: S481-488, 2000.

29) Bassett DR, Jr., Wyatt HR, Thompson H, Peters JC, and Hill JO. Pedometer-measured physical activity and health behaviors in U.S. adults. Med Sci Sports Exerc 42: 1819-1825, 2010.

30) Inoue $\mathrm{S}$, Ohya $\mathrm{Y}$, Tudor-Locke $\mathrm{C}$, Tanaka S, Yoshiike N, and Shimomitsu T. Time Trends for Step-Determined Physical Activity among Japanese Adults. Med Sci Sports Exerc 43: 1913-1919, 2011.

31) Dyck DV, Cardon G, Deforche B, and De Bourdeaudhuij I. Urban-rural differences in physical activity in Belgian adults and the importance of psychosocial factors. J Urban Health 88: 154-167, 2010.

32) Reis JP, Bowles HR, Ainsworth BE, Dubose KD, Smith $\mathrm{S}$, and Laditka JN. Nonoccupational physical activity by degree of urbanization and U.S. geographic region. Med Sci Sports Exerc 36: 2093-2098, 2004.

33) Park J, Ishikawa-Takata K, Tanaka S, Mekata Y, and Tabata I. Effects of walking speed and step frequency on estimation of physical activity using accelerometers. J Physiol Anthropol 30: 119-127, 2011.

34) Le Masurier GC, Sidman CL, and Corbin CB. Accumulating 10,000 steps: does this meet current physical activity guidelines? Res Q Exerc Sport 74: 389-394, 2003. 
35) Feito Y, Bassett DR, and Thompson DL. Evaluation of Activity Monitors in Controlled and Free-Living Environments. Med Sci Sports Exerc Epub ahead of print, 2011.

36) Tudor-Locke C, Hatano Y, Pangrazi RP, and Kang M. Revisiting "how many steps are enough?" Med Sci
Sports Exerc 40: S537-543, 2008.

37）すこやか生活習慣国民運動実行委員会. http://www. kenkounippon21.gr.jp/sukoyaka/00_06.html. 2010.

38）内閣府消費動向調査. http://www.esri.cao.go.jp/jp/stat/ shouhi/shouhi.html. 2011. 